\title{
Morphometric Analysis of Developing Maxillary Sinuses in Human Foetuses
}

\author{
Análisis Morfométrico del Desarrollo de los Senos Maxilares en Fetos Humanos \\ "Ghaus Farah \& ***aruqi Nafis Ahmad
}

FARAH, G. \& NAFIS, A. F. Morphometric analysis of developing maxillary sinuses in human foetuses. Int. J. Morphol., 24(3):303308, 2006.

SUMMARY: The development of the paranasal sinuses, in human race and in many mammals remained as much an enigma as it did nearly two millennia ago. Morphometric analysis of maxillary sinuses in human foetuses are not fully documented and also their morphological studies in Indian population are non-existent. So the present study was conducted to determine the different diameters, the pattern of growth, sexual dimorphism and bilateral variations in maxillary sinuses. 37 human foetuses of different age groups (16 - 34 wks of IUL) were divided into five groups on the basis of age. Maxillary sinuses were dissected out from the nasal aspects of maxillae and their various diameters were measured with the help of Vernier callipers. The percent growth of AP diameter was $+48 \%$ in $17-20$ wks $(\mathrm{p}$ $<0.001)$, of vertical diameter was $+60 \%$ in $17-20$ wks $(\mathrm{p}<0.001)$ and of transverse diameter was $+47 \%$ in $17-20$ wks $(\mathrm{p}<0.001)$. Out of 3 , anteroposterior diameters were maximum throughout foetal life. AP diameters of both sides of a foetus had significant variation ( $\mathrm{p}$ $<0.005)$ in $<17$ wks. AP diameters were invariably more in males but significant variation ( $<<0.001)$ was found only in $26-36$ wks while significant variation $(\mathrm{p}<0.02)$ was observed in transverse diameters in males of 21-25 wks. Anteroposterior dimensions showed faster growth while other diameters were in pace with the head circumference. It was concluded that: 1) Different diameters of maxillary sinus have spurt of growth in different periods of IUL. 2) Values of anteroposterior diameter remain higher, right from the beginning to the end of intra-uterine life. 3) Maxillary sinuses remain relatively larger in males throughout life.

KEY WORDS: Maxillary sinus; Vernier calliper, Morphometry; Growth; Sexual dimorphism.

\section{INTRODUCTION}

Scientists were sincerely concerned about the mystery of paranasal sinuses due to their clinical importance (Mauri et al 2000 and Vaz et al., 2000). Endoscopic surgical intervention in new borns for pediatric sinusitis had further enhanced its importance (McDonald \& Deskin, 1995). The role of the paranasal sinuses in human race and many mammals in general, remained as much an enigma as it did nearly two millennia ago.

Ballantyne et al. (1978) mentioned only the time for the beginning of development of maxillary sinus, Weiglein et al. (1992) described detailed metric analysis of maxillary sinus in humans of postnatal period ( 0 - 12 years of age), while Lund (1988) mentioned early cavitation, rate of growth in anteroposterior diameter, length, height and width of maxillary sinus at birth in human foetus. Negus (1958) described the morphology of maxillary sinus in different animals starting from Monotremes and Marsupials to Primates. Although literature was available providing informations related to development of nasal cavity and paranasal sinuses in human foetuses (Viragh 1997, Wake et al., 1994, Robinson et al., 1982),morphometric analysis of maxillary sinuses in human foetuses are not fully documented ,also their morphological studies in Indian population are non-existent. So, the present study was conducted to find out different diameters in developing human foetuses and to possibly determine the pattern of growth, sexual dimorphism and bilateral variations.

\section{MATERIAL AND METHOD}

Thirty-seven human foetuses, collected from department of obstetrics and gynaecology, J.N. Medical College and Shiva Nursing Home, Aligarh of all age groups without congenital craniovertebral anomalies, were selected for the study and were immersion fixed in $10 \%$ formalin 
saline. Foetuses were divided into five groups on the basis of age. Foetuses below seventeenth week of age were grouped as I, those between 17-20 weeks as II, 21-25 weeks as III, 26-30 weeks as IV and rest of foetuses i.e. above 30 weeks of age formed group V (Table I) using foetal foot length as parameter (Streeter, 1920). After measuring head circumferences and foot lengths, brain was dissected out and face was thoroughly cleaned to expose the maxillae of both the sides. Maxillae were dissected out and isolated from surrounding bones and their ostia were located under the dissecting microscope (Figs.1 and 2). Three parameters, i.e. anteroposterior, vertical and transverse diameters were measured to the nearest tenth of a millimeter and the readings of all the foetuses were grouped according to foetal age. Mean for each group was calculated separately and adjacent readings in terms of per cent change were confirmed statistically by using Student's ' $t$ ' test. Ratio of various diameters to foetal head circumference was also taken to determine relative growth of maxillary sinuses in developing human foetuses.

Table I. Groups of human foetuses

\begin{tabular}{ccccc}
\hline Groups & Age $(\mathbf{w k s})$ & $\mathbf{N}^{\circ}$ of males & $\mathbf{N}^{\circ}$ of females & Total \\
\hline I & $<17$ & 8 & 0 & 8 \\
II & $17-20$ & 10 & 0 & 10 \\
III & $21-25$ & 9 & 1 & 10 \\
IV & $26-30$ & 4 & 2 & 6 \\
V & $>30$ & 2 & 1 & 3 \\
\hline I to V & Grand total & 33 & 4 & 37 \\
\hline
\end{tabular}

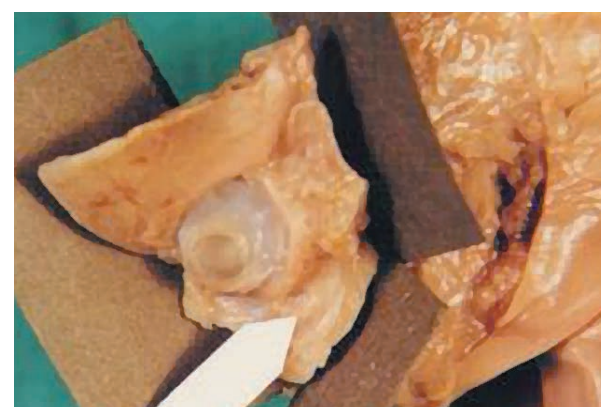

Fig. 1. Left lateral view of the face showing maxilla.

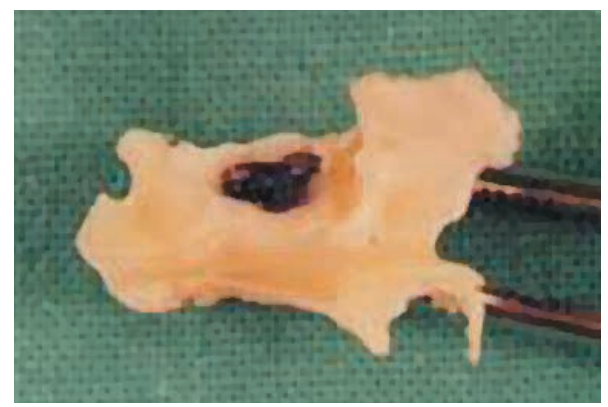

Fig. 2. Left maxilla showing the maxillary sinus. Medial view.
Table II. Anteroposterior diameter ( $\mathrm{mm}$ ) of maxillary sinus in human foetuses.

\begin{tabular}{ccccc}
\hline Groups & $\begin{array}{c}\mathbf{N}^{\mathbf{2}} \\
\text { cases }\end{array}$ & $\begin{array}{c}\text { Mean } \pm \text { SD } \\
(\mathbf{m m})\end{array}$ & $\begin{array}{c}\% \\
\text { change }\end{array}$ & p Value \\
\hline I & 15 & $2.08 \pm 0.4$ & - & \\
II & 19 & $3.07 \pm 0.6$ & +48 & $<0.001$ \\
III & 20 & $3.74 \pm 1.6$ & +22 & $<0.05$ \\
IV & 10 & $6.4 \pm 1.3$ & +71 & $<0.01$ \\
V & 6 & $7.06 \pm 0.7$ & +10 & $<0.05$ \\
\hline
\end{tabular}

Table III. Vertical diameter (mm) of maxillary sinus in human foetuses.

\begin{tabular}{ccccc}
\hline Groups & $\begin{array}{c}\mathbf{N}^{\mathbf{0}} \\
\text { cases }\end{array}$ & $\begin{array}{c}\text { Mean } \pm \text { SD } \\
(\mathbf{m m})\end{array}$ & $\begin{array}{c}\% \\
\text { change }\end{array}$ & p Value \\
\hline I & 15 & $0.86 \pm 0.2$ & - & - \\
II & 19 & $1.38 \pm 0.6$ & +60 & $<0.001$ \\
III & 20 & $1.82 \pm 0.9$ & +32 & $<0.005$ \\
IV & 10 & $2.30 \pm 0.4$ & +26 & $<0.05$ \\
V & 6 & $3.15 \pm 0.4$ & +37 & $<0.005$
\end{tabular}

Table IV. Transverse diameter (mm) of maxillary sinus in human foetuses.

\begin{tabular}{ccccc}
\hline Groups & $\begin{array}{c}\mathbf{N}^{\mathbf{0}} \\
\text { cases }\end{array}$ & $\begin{array}{c}\text { Mean } \pm \text { SD } \\
(\mathbf{m m})\end{array}$ & $\begin{array}{c}\% \\
\text { Change }\end{array}$ & p Value \\
\hline I & 15 & $0.86 \pm 0.2$ & - & - \\
II & 19 & $1.26 \pm 0.5$ & +47 & $<0.001$ \\
III & 20 & $2.07 \pm 1.1$ & +64 & $<0.001$ \\
la- & & & & \\
IV & 10 & $2.21 \pm 0.4$ & +7 & $<0.8$ \\
V & 6 & $2.50 \pm 0.4$ & +13 & $<0.02$ \\
\hline
\end{tabular}

\section{RESULTS}

Anteroposterior diameter of maxillary sinus showed steady growth through out intrauterine life (Table II) but the per cent growth was maximum (+71\%) during 26-30 weeks and appreciable $(+48 \%)$ during $17-20$ weeks. $\mathrm{P}$ value was highly significant $(<0.001)$ in the latter. In the later part of intrauterine life ( $>30$ weeks), the anteroposterior diameter showed minimal growth $(+10 \%)$ (Table II). 
Vertical diameter of maxillary sinus (Table III) was maximally increased $(+60 \%)$ in group II foetuses i.e. 1720 weeks of intrauterine life supported by highly significant $\mathrm{p}$ value $(<0.001)$. Though there was continuity in the growth of this parameter through out foetal life, rate of growth was relatively less during later periods, being minimal during 26-30 weeks of intrauterine life.

Upto 25th week of intrauterine life, there was appreciable growth of transverse diameter (Table IV) i.e. $+47 \%$ during 17 th to 20 th week and $+64 \%$ during $21-25$ weeks of intrauterine life. $p$ value being highly significant $(<0.001)$ in both the cases. Then there was almost stand still till birth. Out of three diameters, anteroposterior diameters were maximum and rest of the two diameters were nearly half of the anteroposterior ones throughout intrauterine life.

The vertical and transverse diameters were nearly equal in all the groups, the latter showed lower values in late foetuses. When values of anteroposterior diameters of maxillary sinuses of the two sides in human foetuses were compared (Table V), it was found that only in smallest available foetal group ( $<17$ weeks of intrauterine life), there was significant variation $(p<0.005)$. In the aforementioned group the value on right side i.e. $2.19 \mathrm{~mm}$ was more than that on left side $(2.00 \mathrm{~mm})$.

Vertical diameter of the maxillary sinuses of two sides showed (Table VI) nearly similar values except in

Table V. Anteroposterior diameter( $\mathrm{mm})$ of the maxillary sinus in human foetuses - bilateral variations.

\begin{tabular}{cccccc}
\hline Groups & Side & $\begin{array}{c}\mathbf{N}^{\circ} \\
\text { cases }\end{array}$ & $\begin{array}{c}\text { Mean } \pm \text { SD } \\
(\mathbf{m m})\end{array}$ & $\begin{array}{c}\% \\
\text { Difference }\end{array}$ & $\begin{array}{c}\mathbf{p} \\
\text { Val ue }\end{array}$ \\
\hline I & Right & 8 & $2.19 \pm 0.50$ & & \\
& Left & 7 & $2.00 \pm 0.44$ & 10 & $<$ \\
& Right & 10 & $3.07 \pm 0.68$ & & \\
II & Left & 9 & $3.12 \pm 0.51$ & 2 & $<0.8$ \\
& Right & 10 & $3.75 \pm 1.60$ & & \\
III & Left & 10 & $3.50 \pm 1.30$ & 7 & $<0.5$ \\
& Right & 5 & $6.56 \pm 1.60$ & & \\
IV & Left & 5 & $6.24 \pm 0.97$ & 5 & $<0.8$ \\
& Right & 3 & $6.94 \pm 0.44$ & & \\
V & Left & 3 & $7.16 \pm 0.88$ & 3 & $<0.8$
\end{tabular}

group III foetuses (21-25 weeks of intrauterine life) where value of left side $(2.04 \mathrm{~mm})$ was more than that $(1.55 \mathrm{~mm})$ of right side. But the p value $(<0.1)$ for this difference was not very significant.

Table VI. Vertical diameter $(\mathrm{mm})$ of the maxillary sinus in human foetuses - bilateral variations.

\begin{tabular}{lccccc}
\hline Groups & Side & $\begin{array}{c}\mathrm{N}^{\circ} \\
\text { cases }\end{array}$ & $\begin{array}{c}\text { Mean } \pm \mathrm{SD} \\
(\mathrm{mm})\end{array}$ & $\begin{array}{c}\% \\
\text { Difference }\end{array}$ & pValue \\
\hline & Right & 8 & $0.81 \pm 0.2$ & & \\
I & Left & 7 & $0.92 \pm 0.3$ & 14 & $<0.2$ \\
& Right & 10 & $1.38 \pm 0.6$ & & \\
II & Left & 9 & $1.35 \pm 0.6$ & 2 & $<0.5$ \\
& Right & 10 & $1.55 \pm 0.6$ & & \\
III & Left & 10 & $2.04 \pm 1.1$ & 32 & $<0.1$ \\
& Right & 5 & $2.38 \pm 0.4$ & & \\
IV & Left & 5 & $2.22 \pm 0.4$ & 7 & $<0.8$ \\
& Right & 3 & $3.13 \pm 0.3$ & & $<0.8$ \\
V & Left & 3 & $3.16 \pm 0.5$ & 1 & \\
& & & &
\end{tabular}

The transverse diameters of maxillary sinuses of two sides (Table VII) showed comparable values with no significant difference.

When anteroposterior diameters of maxillary sinuses in two sexes were compared (Table VIII), the values were found to be invariably more in males than those in females but the highly significant difference $(\mathrm{p}<0.001)$ was noticed only in group IV foetuses $(26-36$ weeks of intrauterine life). Although vertical diameters of maxillary sinuses showed higher values in most of the male foetuses but the difference was not highly significant statistically (Table IX). Like anteroposterior and vertical diameters, transverse diameters of maxillary sinuses also maintained higher values in male (Table X) especially in group III (21-25 weeks of intrauterine life) in which $\mathrm{p}$ value was significant $(<0.02)$. Growth in anteroposterior diameter of maxillary sinus was faster relative to head circumference with variable rates throughout intrauterine life (Table XI).Vertical growth of maxillary sinus on the other hand kept pace with head circumference with increasing age of foetuses (Table XII). Like vertical growth in maxillary sinuses, transverse diameters also showed synchronicity with head circumferences of aging foetuses (Table XIII). 
Table VII. Transverse diameter ( $\mathrm{mm})$ of the maxillary sinus in human foetuses - bilateral variations.

\begin{tabular}{cccccc}
\hline Groups & Side & $\begin{array}{c}\mathbf{N}^{\circ} \\
\text { cases }\end{array}$ & $\begin{array}{c}\text { Mean } \pm \text { SD } \\
(\mathbf{m m})\end{array}$ & $\begin{array}{c}\% \\
\text { difference }\end{array}$ & $\begin{array}{c}\mathbf{p} \\
\text { Value }\end{array}$ \\
\hline I & Right & 8 & $0.81 \pm 0.2$ & & \\
& Left & 7 & $0.92 \pm 0.3$ & 14 & $<0.5$ \\
& Right & 10 & $1.32 \pm 0.5$ & & \\
II & Left & 9 & $1.27 \pm 0.5$ & 4 & $<0.5$ \\
& Right & 10 & $2.05 \pm 1.1$ & & \\
III & Left & 10 & $2.09 \pm 1.0$ & 2 & $<0.8$ \\
& Right & 5 & $2.02 \pm 0.16$ & & \\
IV & Left & 5 & $2.40 \pm 0.5$ & 19 & $<0.2$ \\
& Right & 3 & $2.50 \pm 0.16$ & & \\
& & & & & \\
V & Left & 3 & $2.50 \pm 0.60$ & 0 & $<0.8$ \\
& & & & & \\
\hline
\end{tabular}

Table VIII. Anteroposterior diameter ( $\mathrm{mm}$ ) of the maxillary sinus in human foetuses - sexual dimorphism.

\begin{tabular}{llcccc}
\hline Groups & Sex & $\begin{array}{c}\mathbf{N}^{\circ} \\
\text { cases }\end{array}$ & $\begin{array}{c}\text { Mean } \pm \text { SD } \\
(\mathbf{m m})\end{array}$ & $\begin{array}{c}\% \\
\text { difference }\end{array}$ & $\begin{array}{c}\mathbf{p} \\
\text { Value }\end{array}$ \\
\hline \multirow{2}{*}{ III } & Male & 18 & $3.70 \pm 1.5$ & & \\
& Female & 2 & $3.20 \pm 0.3$ & 16 & $<0.1$ \\
& Male & 6 & $7.18 \pm 1.0$ & & \\
IV & Female & 4 & $5.2 \pm 0.8$ & 38 & $<$ \\
& Male & 4 & $7.32 \pm 0.7$ & & \\
& & & & & \\
V & Female & 2 & $6.50 \pm 0.1$ & 13 & $<0.1$ \\
\hline
\end{tabular}

Table IX. Vertical diameter (mm) of the maxillary sinus in human foetuses - sexual dimorphism.

\begin{tabular}{llcccc}
\hline Groups & Sex & $\begin{array}{c}\mathbf{N}^{\mathbf{0}} \\
\text { cases }\end{array}$ & $\begin{array}{c}\text { Mean } \pm \text { SD } \\
(\mathbf{m m})\end{array}$ & $\begin{array}{c}\% \\
\text { difference }\end{array}$ & pValue \\
\hline \multirow{2}{*}{ III } & Male & 18 & $1.84 \pm 0.1$ & & \\
& Female & 2 & $1.35 \pm 0.05$ & 36 & $<0.1$ \\
& Male & 6 & $2.30 \pm 0.40$ & & \\
IV & Female & 4 & $2.30 \pm 0.33$ & 0 & $<0.8$ \\
& Male & 4 & $3.25 \pm 0.50$ & & \\
V & Female & 2 & $2.95 \pm 0.20$ & 10 & $<0.5$ \\
\end{tabular}

Table X. Transverse diameter ( $\mathrm{mm}$ ) of the maxillary sinus in human foetuses - sexual dimorphism.

\begin{tabular}{llcccc}
\hline Groups & Sex & $\begin{array}{c}\mathbf{N}^{\circ} \\
\text { cases }\end{array}$ & $\begin{array}{c}\text { Mean } \pm \text { SD } \\
(\mathbf{m m})\end{array}$ & $\begin{array}{c}\% \\
\text { difference }\end{array}$ & $\begin{array}{c}\mathbf{p} \\
\text { Value }\end{array}$ \\
\hline \multirow{4}{*}{ III } & Male & 18 & $2.18 \pm 1.1$ & & \\
& & & & & \\
& Female & 2 & $1.52 \pm$ & 43 & $<0.02$ \\
& & & 0.10 & & \\
IV & Male & 6 & $2.15 \pm$ & & \\
& Female & 4 & $2.32 \pm$ & 8 & $<0.2$ \\
& & & 0.40 & & \\
& Male & 4 & $2.70 \pm$ & & \\
V & Female & 2 & $2.10 \pm$ & 29 & $<0.1$ \\
& & & 0.40 & &
\end{tabular}

Table XI. Anteroposterior diameter (APD) of max. sinus versus head circumference (HC).

\begin{tabular}{ccccc}
\hline Groups & $\begin{array}{c}\text { APD } \\
\text { Mean } \pm \text { SD } \\
(\mathbf{m m})\end{array}$ & $\begin{array}{c}\text { HC } \\
\text { Mean } \pm \text { SD } \\
(\mathbf{m m})\end{array}$ & $\begin{array}{c}\text { (APD:HC) } \\
\text { Mean } \pm \text { SD } \\
(\mathbf{m m})\end{array}$ & $\begin{array}{c}\mathbf{p} \\
\text { Value }\end{array}$ \\
\hline I & $2.08 \pm 0.40$ & $111.88 \pm 13.7$ & $0.018 \pm 0.002$ & - \\
II & $3.07 \pm 0.60$ & $138.50 \pm 14.7$ & $0.023 \pm 0.003$ & $<0.001$ \\
III & $3.74 \pm 1.60$ & $188.50 \pm 23.1$ & $0.019 \pm 0.005$ & $<0.005$ \\
& & & & \\
IV & $6.40 \pm 1.30$ & $242.50 \pm 30.5$ & $0.026 \pm 0.003$ & $<0.001$ \\
& & & & \\
V & $7.06 \pm 0.70$ & $290.00 \pm 21.6$ & $0.024 \pm 0.001$ & $<0.2$ \\
\hline
\end{tabular}

Table XII. Vertical diameter (VD) of maxillary sinus versus head circumference (HC).

\begin{tabular}{ccccc}
\hline Groups & $\begin{array}{c}\text { VD } \\
\text { Mean } \pm \text { SD } \\
(\mathbf{m m})\end{array}$ & $\begin{array}{c}\text { HC } \\
\text { Mean } \pm \text { SD } \\
(\mathbf{m m})\end{array}$ & $\begin{array}{c}(\text { VD }: \text { HC) } \\
\text { Mean } \pm \text { SD } \\
(\mathbf{m m})\end{array}$ & p Value \\
\hline I & $0.86 \pm 0.2$ & $111.8 \pm 13.7$ & $0.007 \pm 0.001$ & - \\
II & $1.38 \pm 0.6$ & $138.5 \pm 14.7$ & $0.01 \pm 0.005$ & $<0.1$ \\
III & $1.82 \pm 0.9$ & $188.5 \pm 23.1$ & $0.008 \pm 0.004$ & $<0.05$ \\
& & & & \\
IV & $2.30 \pm 0.4$ & $242.5 \pm 30.5$ & $0.009 \pm 0.002$ & $<0.5$ \\
& & & & \\
V & $3.15 \pm 0.4$ & $290.0 \pm 21.6$ & $0.01 \pm 0.002$ & $<0.5$ \\
\hline
\end{tabular}


Table XIII. Transverse diameter (TD) of maxillary sinus versus head circumference (HC).

\begin{tabular}{ccccc}
\hline Groups & $\begin{array}{c}\text { TD } \\
\text { Mean } \pm \\
\text { SD }(\mathbf{m m})\end{array}$ & $\begin{array}{c}\text { HC } \\
\text { Mean } \pm \text { SD } \\
(\mathbf{m m})\end{array}$ & $\begin{array}{c}(\text { TD }: \text { HC) } \\
\text { Mean } \pm \text { SD } \\
(\mathbf{m m})\end{array}$ & $\begin{array}{c}\mathbf{p} \\
\text { Value }\end{array}$ \\
\hline I & $0.86 \pm 0.2$ & $111.8 \pm 13.7$ & $0.007 \pm 0.001$ & - \\
II & $1.26 \pm 0.5$ & $138.5 \pm 14.7$ & $0.007 \pm 0.003$ & $<0.8$ \\
& & & & \\
III & $2.07 \pm 1.1$ & $188.5 \pm 23.1$ & $0.010 \pm 0.006$ & $<0.1$ \\
& & & & \\
IV & $2.21 \pm 0.4$ & $2425 \pm 30.5$ & $0.010 \pm 0.003$ & $<0.8$ \\
& & & & $<0.2$ \\
V & $2.50 \pm 0.4$ & $290.0 \pm 21.6$ & $0.008 \pm 0.001$ & \\
\hline
\end{tabular}

\section{DISCUSSION}

The variable growth rate of paranasal sinuses observed in the present study received support from the study of Koppe et al. (2000) in the miniature pig, in which they reported an increased growth rate of maxillary sinus until 4 months of intra-uterine life. They reported that from the first day of appearance, maxillary sinus expanded not only in posterior direction but also in anterior direction from 11 weeks onwards. The steadily increased anteroposterior diameter with variable speed, observed in the present study was also noticed by Koppe et al. (1994). Greater anteroposterior diameter compared to two remaining dimensions was also highlighted by Croydon et al (1999). Hengerer (1984) reported the anteroposterior diameter as $7 \mathrm{~mm}$ while Ballenger (1996) reported the same as $7-8 \mathrm{~mm}$, the measurements very close to our finding (7.06 \pm 0.7$)$ in late foetuses. Hengerer described the vertical height as $4 \mathrm{~mm}$ in new born, the value is quite high as compared to our measurement in late foetuses. Vidic (1971) reported the vertical diameter of $3.5 \mathrm{~mm}$ at $145 \mathrm{~mm}$ Crown Rump Length (CRL) and $7.5 \mathrm{~mm}$ at $210 \mathrm{~mm}$ CRL. Growth of vertical diameter seemed to be a continuous phenomenon after birth and thus brought the measurement almost equal to anteroposterior diameter in adults. Adult vertical heights were described differently by different authors. It was $35 \mathrm{~mm}$ according to Murray (2000). Hengerer had shown the transverse diameter at birth as $4 \mathrm{~mm}$, which is quite high in comparison to our finding $(2.50 \pm 0.60)$ in late foetuses, which may be due to continuous side to side growth till birth. Ballenger reported the anteroposterior diameter as $7-8 \mathrm{~mm}$ at birth, this value being quite high as compared to width of 4-6 mm. This ratio of length to width was maintained even in adult (31-32 $\mathrm{mm} \times 18-20 \mathrm{~mm})$. With little variations, other authors also supported this view The length and width was $30 \mathrm{~mm}$ x $25 \mathrm{~mm}$ according to Murray. Robinson et al. (1982) provided informations about maxillary sinus measurements in cleft palate patients as compared with those of normal palates. They reported the anteroposterior length, height and width of sinus at birth as $7 \mathrm{~mm}, 4 \mathrm{~mm}$ and $4 \mathrm{~mm}$, respectively, which were very close to our findings in late foetuses. While Wolf et al. (1993) described the measurements as $10 \mathrm{~mm}$ long, $4 \mathrm{~mm}$ height and $3 \mathrm{~mm}$ wide which maintained the ratio observed in the present study. Koppe \& Nagai (1997) reported a large maxillary sinus of right side in Japanese macaque, while Watelet and Cauvenberge (1999) had appreciated frequent bilateral variations in adult human maxillary sinuses. Although in our study bilateral variations were noticed,but only in few foetuses and that only involving some parameters, the values were always higher on right side. Koppe et al. (2000) reported sexual dimorphism of maxillary sinus size in pig tailed macaque and pongo pygmaeus while Arreola et al. (1996) found no sexual dimorphism in human embryos/foetuses from 6 to 36 weeks of age.

Alterations of the craniofacial morphology during the evolution of the hominids was considered as an important factor affecting the maxillary sinus morphology (Proctor \& Naclerio, 1996). Koppe \& Nagai (1997) on the basis of their correlation analysis showed close relationships between the maxillary sinus volume and external cranial dimensions in the skulls of Japanese macaque while Koppe et al. (2000) concluded that growth in the maxillary sinus size in the miniature pigs did not follow the growth pattern of skull. In the present study a strong correlation between at least two dimensions of maxillary sinus (i.e. vertical and transverse) and head circumference was observed which can be compared with variable growth rate of different dimensions of maxillary sinus during intrauterine life and after birth reported by Robinson et al.; Hengerer; Weiglein et al. and Wolf et al.

Relative size of maxillary sinus in various species as reported by Negus, reflected some light on the factors influencing morphology of maxillary sinus. Very small size was observed in rodents (hare, squirrel, guinea pig and rat) and very big sinus was noticed in highly evolved species (gorilla, man). Hanson et al. (1980) found that Canadian Eskimo, from the region surrounding the Hudson Bay had smaller sinus areas than those reported for Alaskan Eskimo and Grand Quivera Pueblo, Arikara and Zuni Indians indicating some role of geographical location in maxillary sinus growth. It was concluded that 1) Different diameters of maxillary sinus have spurt of growth in different periods of intrauterine life. 2) Values of anteroposterior diameter remain higher, right from the beginning till the end of intra-uterine life. 3) Maxillary sinuses remain relatively larger in males throughout life. 
FARAH, G. \& NAFIS, A. F. Análisis morfométrico del desarrollo de los senos maxilares en fetos humanos. Int. J. Morphol., 24(3):303-308, 2006.

RESUMEN: El desarrollo de los senos paranasales en humanos y en muchos mamíferos ha permanecido como un enigma hace ya varios milenios. Análisis morfométricos de los senos maxilares en fetos humanos no han sido suficientemente documentados y en la India son inexistentes. El presente estudio fue llevado a cabo para determinar los diferentes diámetros, el padrón de crecimiento, el dimorfismo sexual y las variaciones bilaterales en los senos maxilares de 37 fetos humanos de diferentes edades (16-34 semanas de vida intrauterina), los cuales fueron divididos en 5 grupos etarios. Los senos maxilares fueron disecados por la parte nasal del maxilar y los diversos diámetros fueron medidos con la ayuda de un caliper. El crecimiento porcentual del diámetro AP fue $+48 \%$ en los fetos de $17-20$ semanas $(\mathrm{p}<0.001$ ), el diámetro vertical fue de $+60 \%$ ( $<<0.001)$. Los diámetros AP de ambos lados de un feto tuvieron una variación significativa $(\mathrm{p}<0.005)$ en menores de 17 semanas. Los diámetros AP fueron invariablemente mayores en fetos masculinos, pero una variación significativa $(\mathrm{p}<0.001)$ fue encontrada solamente en individuos de 26 a 36 semanas, mientras que una variación significativa $(\mathrm{p}<0.02)$ fue observada en los diámetros transversos en fetos masculinos de 21-25 semanas. Las dimensiones anteroposteriores mostraron un crecimiento más rápido, mientras que otros diámetros fueron en concordancia con la circcunferencia craneal. Se puede concluir que: 1) Diámetros diferentes del seno maxilar tienen una aceleración de crecimiento en diferentes periodos de la vida intrauterina. 2) Valores de los diámetros AP permanecen más altos, desde el inicio al término de la vida intrauterina. 3) Los senos maxilares permanecen relativamente más amplios en fetos masculinos a través de su vida.

PALABRAS CLAVE: Seno maxilar; Caliper Morfometría; Crecimiento; Dimorfismo sexual.

\section{REFERENCES}

Arreola, G. A. and et al. Morphogenesis of the lateral nasal wall from 6 to 36 weeks. Otolaryngol. Head and Neck Surg., 114:54-60, 1996.

Ballantyne, J. C. and et al. A synopsis of otolaryngology. $3^{\text {th }}$ Ed. Varghese, Mumbai, 1978. pp. 161-2.

Ballenger, J. J. Clinical anatomy and physiology of the nose and the paranasal sinuses. In: Otorhinolaryngology Head and Neck Surgery. $15^{\text {th }}$ ed. Williams \& Wilkins, 1996. pp. 1-18.

Croydon, A.T. and et al. Mesencephalic innervation of the vibrissal follicle-sinus complex in the mouse embryo. Int. J. Dev. Neurosc. 17(4):401-9, 1999.

Hanson and et al. Frontal sinus size in Eskimo populations. Am. J. Physical Anthropol., 53:251-5, 1980.

Hengerer, A. S. Embryologic development of the sinuses: Ear, Nose and Throat Journal, 63:134-6, 1984.

Koppe, T. and et al. Growth pattern of the maxillary sinus in the miniature pig (Sus Scrofa). Cells Tissues and Organs, 167:5867,2000

Koppe, T. \& Nagai, H. Growth pattern of the maxillary sinus in the Japanese Macaque (Macaca fuscata): reflections on the structural role of the paranasal sinus. J. Anat., 190 (pt 4):533-44, 1997.

Koppe, T. and et al. Investigation on the growth pattern of the maxillary sinus in Japanese human fetuses. Okajimas Folia Anat. Jpn. 71(5):311-8, 1994.

Lund, V. J. The maxillary sinus in the higher primates. Arch Otolaryngol., 105:163-71, 1988.

Mauri, M. and et al. Pneumosinus dilatans of the maxillary sinus. Ann. Otol. Rhinol. Laryngol., 109:278-80, 2000.

Mc Donald, K. \& Deskin, R. Textbook of Otolaryngology. In: Functional endoscopic sinus surgery for pediatric sinusitis. Grand Rounds, Archive, 1995. pp. 1-10.

Murray, J. A. M. Anatomy and Physiology In Logan Turner's Diseases of the nose, throat and ear. $10^{\text {th }}$ Ed. Maran AGD, KM Verghese, 2000. pp. 3-12.
Negus, V. The comparative anatomy and physiology of the nose and paranasal sinuses. Edinburgh, Livingstone, 1958. pp. 286-327.

Proctor, T. \& Naclerio, R. Imaging case study of the month: Development of a hypoplastic maxillary sinus. Ann. Otol. Rhinol. Laryngol., 105:327-8, 1996.

Robinson, H. E. and et al. Maxillary sinus development in patients with cleft palates as compared to those with normal palates. Laryngoscope, 92:183-7, 1982.

Streeter, G. L. Weight,sitting height,head size, foot length and menstrual age for human embryo. Contribution to embryology 11,143, 1920.

Vaz, F. and et al. Congenital maxillary sinus cholesteatoma. Int. J. Ped. Otorhinolaryngol., 52:283-6, 2000.

Vidic, B. The morphogenesis of the lateral nasal wall in the early prenatal life of man. Am. J. Anat., 130:121-40, 1971.

Viragh, H. S. Histological investigations of the nasal mucosa in human fetuses. Arch. Otorhinolaryngol., 254 (Suppl 1):S39-S42, 1997.

Wake, M. and et al. The early development of sinonasal mucosa. Laryngoscope, 104:850-5, 1994.

Watelet, J. B. \& Cauvenberge, P. V. Applied anatomy and physiology of the nose and paranasal sinuses. Allergy, 54(Suppl 57):14-25, 1999.

Weiglein, A. and et al. Radiologic anatomy of the paranasal sinuses in the child. Surg. Radiol. Anat., 14:335-9, 1992.

Wolf, G. and et al. Development of the paranasal sinus in children: Implications for paranasal sinus surgery. Ann. Otol. Rhinol. Laryngol., 102:705-11, 1993.

Correspondence to:

Dr. Ghaus Farah

Department of Anatomy,

Jawaharlal Nehru Medical College,

Aligarh Muslim University,

Aligarh - INDDIA

Email:drfarahghaus@rediffmail.com drfarahghaus@gmail.com

Received :03-03-2006 Accepted:12-05-2006 